\title{
Effects of low-intensity pulsed ultrasound and hyperbaric oxygen on human osteoarthritic chondrocytes
}

\author{
Li-Jen Yuan ${ }^{1 \dagger}$, Chi-Chien Niu ${ }^{1 \dagger}$, Song-Shu Lin ${ }^{1,2}$, Chuen-Yung Yang ${ }^{1}$, Yi-Sheng Chan ${ }^{1}$, Wen-Jer Chen ${ }^{1}$ \\ and Steve WN Ueng ${ }^{1 *}$
}

\begin{abstract}
Background: Although the individual effects of hyperbaric oxygen $(\mathrm{HBO})$ and low-intensity pulsed ultrasound (LIPUS) on osteoarthritic (OA) chondrocytes have been reported, the effects of HBO combined with LIPUS treatment are unknown.

Methods: OA chondrocytes were obtained from patients undergoing knee replacement surgery. RNA was isolated for real-time polymerase chain reaction (PCR) analysis of inducible nitric oxide synthase (iNOS), type-Il collagen, and aggrecan gene expression. The protein levels of MMP-3 and TIMP-1 were quantified by enzyme-linked immunosorbent assay (ELISA) after LIPUS or HBO treatment. The data are given as mean \pm standard deviation (SD) of the results from three independent experiments. A $p$ value less than 0.05 was defined as statistically significant.

Results: Our data suggested that ultrasound and HBO treatment increased cell bioactivity of OA chondrocytes. Real-time PCR analysis showed that HBO treatment increased the mRNA of type-II collagen, aggrecan, and TIMP-1 but suppressed the iNOS expression of OA chondrocytes. LIPUS treatment increased the type-II collagen and iNOS expression of OA chondrocytes. ELISA data showed that HBO or LIPUS treatment increased TIMP-1 production of OA chondrocyte. MMP-3 production was suppressed by HBO treatment. HBO combined with LIPUS treatments resulted in additive effect in TIMP-1 production and compensatory effect in iNOS expression.
\end{abstract}

Conclusion: HBO combined with LIPUS treatment-induced increase of the anabolic factor (TIMP-1)/catabolic factor (MMP-3) ratio may provide an additive therapeutic approach to slow the course of OA degeneration.

Keywords: Low-intensity pulsed ultrasound, Hyperbaric oxygen, Osteoarthritis, TIMP-1, MMP-3, Aggrecan, Type-ll collagen

\section{Background}

Mechanical stimulus is thought to be one of the important factors regulating chondrocyte metabolism [1]. Excessive mechanical stimulus has been reported to destroy articular cartilage directly and also induce other destructive factors [2]. Conversely, insufficient mechanical stimulus, such as that due to joint immobilization, has also been associated with cartilage destruction [3]. On the other hand, moderate (physiological) mechanical stimulus

\footnotetext{
* Correspondence: wenneng@adm.cgmh.org.tw

${ }^{\dagger}$ Equal contributors

'Department of Orthopaedic Surgery, Chang Gung Memorial Hospital, 5, Fu-Hsin St. 333, Kweishan, Taoyuan 333, Taiwan

Full list of author information is available at the end of the article
}

has been confirmed not only to promote articular cartilage anabolism [4] but also to inhibit catabolism [5,6].

Low-intensity pulsed ultrasound (LIPUS) is a representative therapy in the orthopedic field and is clinically used to treat fractures with nonunion and to promote bone union [7]. Application of high-intensity continuous ultrasound $\left(1-300 \mathrm{~W} / \mathrm{cm}^{2}\right)$ generates considerable heat in living tissues. In contrast, LIPUS $\left(<100 \mathrm{~mW} / \mathrm{cm}^{2}\right)$ has much lower intensities with nonthermogenic and nondestructive actions. Mechanical strains received in the skeleton result in the promotion of bone formation, possibly by inducing chondrocyte proliferation $[8,9]$. In this context, LIPUS has been shown to enhance the endochondral 
ossification in the healing process of fractured bones $[10,11]$.

Ultrasound treatment has been tried as an approach to encourage cartilage repair [12]. Previous in vitro work has shown that the expression levels of integrins a 5 and b1, as well as chondrocytic markers, Sox5, Sox9, collagen II, and aggrecan, were increased in chondrocytes exposed to a continuous ultrasound signal at $5.0 \mathrm{MHz}$ $\left(0.14 \mathrm{~mW} / \mathrm{cm}^{2}\right)$ [13]. Previous in vivo study in a New Zealand rabbit that modeled full-thickness osteochondral defects has demonstrated that exposure to LIPUS significantly improves the morphologic features and histologic characteristics of repaired cartilage [14]. Another in vivo experimental rat osteoarthritis model also demonstrated efficacy in cartilage restoration [15]. Exposure to LIPUS could significantly affect chondrocyte proliferation, phenotype expression, and matrix production; however, inconsistent effects were also observed.

Previous report suggested that VEGF induced by HBO is through c-Jun/AP-1 activation and through simultaneous activation of ERK and JNK pathways in umbilical vein endothelial cells [16]. HBO-suppressed ERK1/2 and p38 MAPK mediate nitric oxide-induced apoptosis on human degenerated intervertebral disc cells [17]. In OA chondrocytes, the MAP kinases, AP-1, and NF- $\kappa B$ transcription factors have been shown to play a predominant role in the expression of metalloproteinases (MMPs) and inflammatory genes and protein [18]. Our previous study demonstrated that attenuation of apoptosis and enhancement of proteoglycan synthesis in rabbit cartilage defects by HBO treatment are related to the suppression of IL-1 $\beta$ and nitric oxide (NO) production [19]. HBO treatment prevents NO-induced apoptosis in articular cartilage injury via enhancement of the expression of heat shock protein 70 [20].

Although the individual effect of $\mathrm{HBO}$ or LIPUS on the chondrocytes have been reported, the effect of $\mathrm{HBO}$ combined with LIPUS treatment is still controversial. We harvested the articular cartilage from patients who receive total knee arthroplasty (TKA). We investigate whether the beneficial effect on OA will be synergistic up-regulation (such as aggrecan, type-II collagen, and TIMP-1 expression) and the subversive effect will be complementary compensation (such as iNOs expression) after $\mathrm{HBO}$ combined with LIPUS treatment.

\section{Methods}

The experimental protocol was approved by the Human Subjects Institutional Review Board of the Chang Gung Memorial Hospital.

\section{Cell isolation and cell culture}

Articular cartilage specimens (tibial plateaus and femoral condyles) were obtained from 20 Ahlbäck grade IV or
Kellgren and Lawrence grade IV OA patients who receive TKA surgery. The specimen was obtained under aseptic conditions, and the cartilage was dissected on ice. The chondrocytes were released from the articular cartilage by sequential digestion with $1 \mathrm{mg} / \mathrm{ml}$ collagenase (Sigma, St. Louis, MO, USA) in Dulbecco's minimal essential medium (DMEM/F-12) (Gibco, Grand Island, NY, USA) containing 5\% fetal bovine serum (FBS) and incubated at $37^{\circ} \mathrm{C}$ until the fragments were digested. The isolated chondrocytes were centrifuged $(1,000 \mathrm{rpm}$ for $5 \mathrm{~min}$ ), washed with PBS, and seeded in T-75 tissue culture flasks (Falcon, BD Biosciences, Drive Franklin Lakes, NJ, USA) in $15 \mathrm{ml}$ of medium (DMEM/F-12) supplemented with 20\% $(v / v)$ FBS and antibiotics (mixture of $100 \mathrm{U} / \mathrm{ml}$ of penicillin and $100 \mu \mathrm{g} / \mathrm{ml}$ of streptomycin; Gibco). The cultures were incubated in a humidified atmosphere of $5 \% \mathrm{CO}_{2} / 95 \%$ air until cell confluence.

\section{Cell exposure to intermittent $\mathrm{HBO}$}

About $3 \times 10^{4}$ cells are platted on the $35-\mathrm{mm}$ cell culture dish (Falcon) with medium (DMEM/F-12) containing 10\% FBS and incubated at $37^{\circ} \mathrm{C}$ in a humidified atmosphere of $5 \% \mathrm{CO}_{2}$ and $95 \%$ air. Control cells were maintained in 5\% $\mathrm{CO}_{2} / 95 \%$ air (non-HBO) through the experimental protocol. All hyperoxic cells were exposed to $100 \% \mathrm{O}_{2}$ for $25 \mathrm{~min}$ then to air for $5 \mathrm{~min}$ at 2.5 atmospheres absolute (ATA) in a hyperbaric chamber (Sigma II, Perry Baromedical Corporation, Riviera Beach, FL, USA) with a total treatment of $90 \mathrm{~min}$ per $48 \mathrm{~h}$.

\section{Cell exposure to LIPUS treatment}

About $3 \times 10^{4}$ cells are platted on the $35-\mathrm{mm}$ cell culture dish with medium (DMEM/F-12) containing 10\% FBS and incubated at $37^{\circ} \mathrm{C}$ in a humidified atmosphere of $5 \%$ $\mathrm{CO}_{2}$ and $95 \%$ air. A UV-sterilized transducer (Exogene 3000; Smith \& Nephew Inc., Memphis, TN, USA) that generated $1.5-\mathrm{MHz}$ US in a pulsed-wave mode $(200-\mu \mathrm{s}$ pulse burst width with repetitive frequency of $1 \mathrm{kHz}$ at an intensity of $30 \mathrm{~mW} / \mathrm{cm}^{2}$ ) was immersed vertically into each culture well and placed to just contact the surface of the medium. The distance between the transducer and the cells was approximately $5-6 \mathrm{~mm}$. The exposure time was 20 min per $48 \mathrm{~h}$.

\section{Cell exposure to LIPUS combined with HBO}

The cells were treated with LIPUS first and then with $\mathrm{HBO}$ as previously described.

\section{RNA extraction and real-time $P C R$ analysis}

At $24 \mathrm{~h}$ after each treatment, cellular RNA was isolated using an RNeasy mini kit (Qiagen, Valencia, CA, USA) and reverse-transcribed into cDNA with the ImProm-II reverse transcription system (Promega, Madison, WI, USA). For real-time PCR detection of iNOs, aggrecan, 
and type-II collagen RNA transcripts, cDNA was analyzed on an ABI PRISM 7900 sequence detection system using the TaqMan PCR Master Mix (Applied Biosystems, Foster City, CA, USA). The cycle threshold (Ct) values were obtained, and the data was normalized to GAPDH expression using the $\Delta \Delta \mathrm{Ct}$ method to calculate relative mRNA levels of each target gene.

\section{MMP-3 ELISA assay}

The cells were plated at $3 \times 10^{4}$ cells per $35-\mathrm{mm}$ tissue culture dish (Falcon) in $2.5 \mathrm{ml}$ of medium (DMEM/ F-12) containing 5\% FBS. The level of TIMP-1 in the conditioned media after each treatment was determined using a commercial immunoassay kit (Quantikine Human TIMP-1, R\&D System, Minneapolis, MN, USA). At intervals of 48,96 , and $144 \mathrm{~h}, 200 \mu \mathrm{l}$ of conditioned media was accumulated and tested according to the manufacturer's instructions. The measurements were performed in triplicate.

\section{TIMP-1 ELISA assay}

The cells were plated at $3 \times 10^{4}$ cells per $35-\mathrm{mm}$ tissue culture dish in $2.5 \mathrm{ml}$ of medium (DMEM/F-12) containing 5\% FBS. The level of TIMP-1 in the conditioned media after each treatment was determined using a commercial immunoassay kit (Quantikine Human TIMP-1, R\&D System). At intervals of 48, 96, and 144 h, $200 \mu \mathrm{l}$ of conditioned media was accumulated and tested according to the manufacturer's instructions. The measurements were performed in triplicate.

\section{Results}

Effect of HBO and LIPUS on MMP-3 production

Figure 1 shows the effect of HBO, LIPUS, and HBO combined with $\mathrm{HBO}$ on MMP-3 production (data are presented as mean $\pm \mathrm{SD}$; control group vs. HBO group:

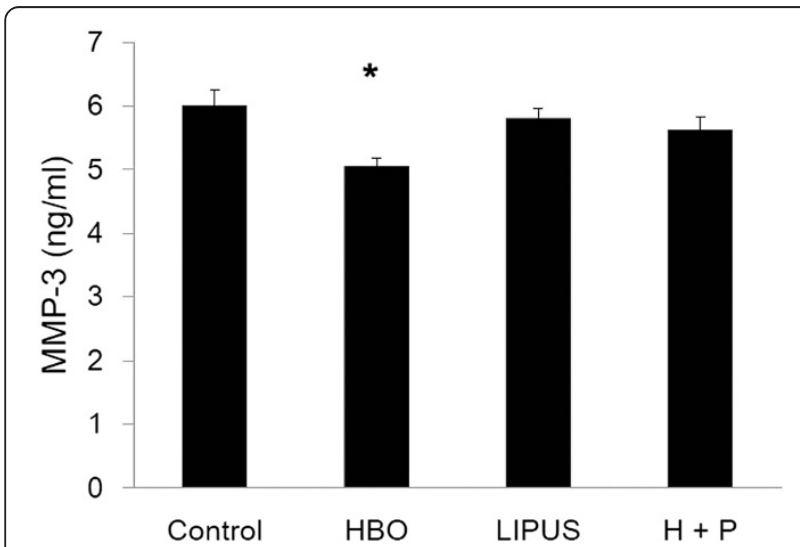

Figure 1 Effect of HBO and LIPUS on MMP-3 production. MMP-3 production in $\mathrm{OA}$ chondrocytes was significantly down-regulated by the $\mathrm{HBO}$ treatment $\left({ }^{*} p<0.05\right)$.
$6.01 \pm 0.23 \mathrm{ng} / \mathrm{ml}$ vs. $5.05 \pm 0.12 \mathrm{ng} / \mathrm{ml}, p<0.05$; control group vs. LIPUS group: $6.01 \pm 0.23 \mathrm{ng} / \mathrm{ml}$ vs. $5.81 \pm$ $0.15 \mathrm{ng} / \mathrm{ml}, p>0.05$; control group vs. ILPUS $+\mathrm{HBO}$ group: $6.01 \pm 0.23 \mathrm{ng} / \mathrm{ml}$ vs. $5.62 \pm 0.21 \mathrm{ng} / \mathrm{ml}, p>0.05$, $n=3)$. The MMP-3 production in OA chondrocytes was significantly down-regulated by the $\mathrm{HBO}$ treatment.

\section{Effect of HBO and LIPUS on TIMP-1 production}

Figure 2 shows the effect of $\mathrm{HBO}$, LIPUS, and $\mathrm{HBO}$ combined with $\mathrm{HBO}$ on TIMP-1 production (data are presented as mean $\pm \mathrm{SD}$; control group vs. HBO group: $0.85 \pm 0.06 \mathrm{ng} / \mathrm{ml}$ vs. $1.23 \pm 0.12 \mathrm{ng} / \mathrm{ml}, p<0.05$; control group vs. LIPUS group: $0.85 \pm 0.06 \mathrm{ng} / \mathrm{ml}$ vs. $1.26 \pm$ $0.05 \mathrm{ng} / \mathrm{ml}, p<0.05$; control group vs. LIPUS $+\mathrm{HBO}$ group: $0.85 \pm 0.06 \mathrm{ng} / \mathrm{ml}$ vs. $1.89 \pm 0.09 \mathrm{ng} / \mathrm{ml}, p<0.01$, $n=3)$. The TIMP-1 production in OA chondrocytes was significantly up-regulated by the $\mathrm{HBO}$ and LIPUS treatment. In addition, the $\mathrm{HBO}$ combined with LIPUS treatment resulted in an additive effect in the TIMP-1 production.

\section{Effect of HBO and LIPUS on gene expression of iNOs,} aggrecan, and type-II collagen

Figures 3, 4, and 5 show the effects of HBO and LIPUS on transcription of iNOs (data are presented as mean $\pm \mathrm{SD}$; HBO group/control group: $0.69 \pm 0.07$ fold, $p<0.05$; LIPUS group/control group: $1.49 \pm 0.11$ fold, $p<0.05$; $\mathrm{HBO}+$ LIPUS group/control group: $0.95 \pm 0.12$ fold, $p>0.05 ; n=3$; Figure 3 ), aggrecan (data are presented as mean $\pm \mathrm{SD}$; HBO group/control group: $2.25 \pm 0.32$ fold, $p<0.05$; LIPUS group/control group: $1.14 \pm 0.15$ fold, $p>0.05$; $\mathrm{HBO}+$ LIPUS group/control group: $2.01 \pm$ 0.12 fold, $p<0.05 ; n=3$; Figure 4 ), and type-II collagen (data are presented as mean $\pm \mathrm{SD}$; HBO group/control group: $1.57 \pm 0.22$ fold, $p<0.05$; LIPUS group/control

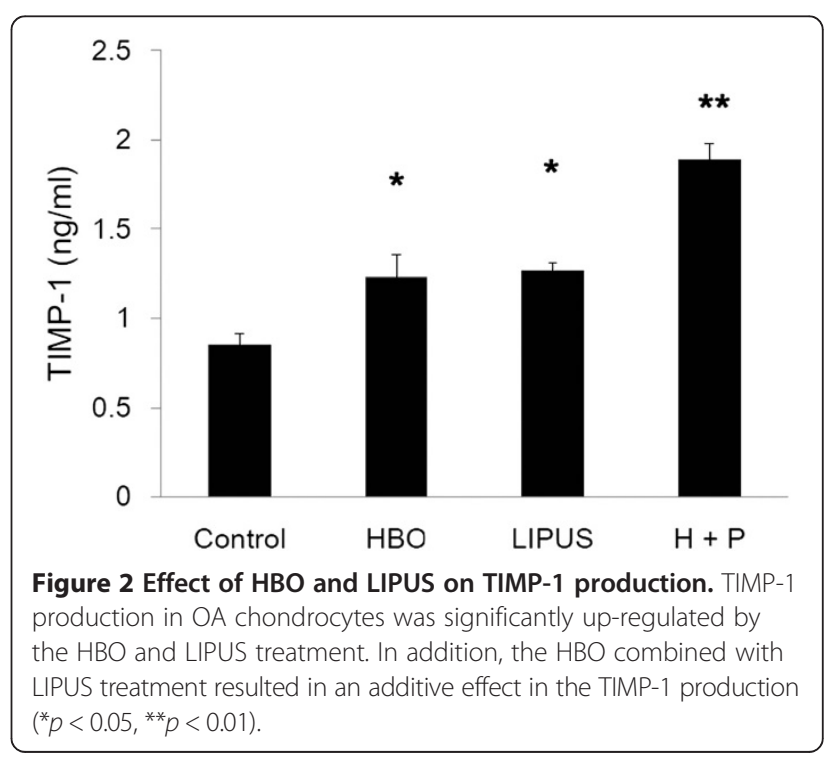




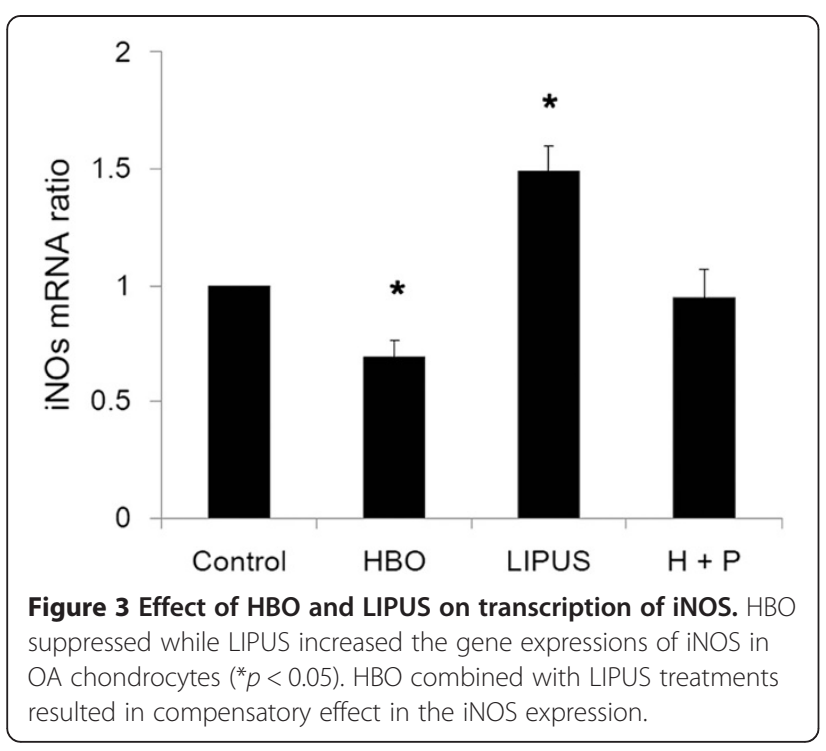

group: $1.68 \pm 0.15$ fold, $p<0.05 ; \mathrm{HBO}+$ LIPUS group/ control group: $1.51 \pm 0.12$ fold, $p<0.05 ; n=3$; Figure 5) in OA chondrocytes. HBO suppressed while LIPUS increased the gene expressions of iNOS in OA chondrocytes. $\mathrm{HBO}$ combined with LIPUS treatments resulted in compensatory effect in iNOS expression (Figure 3). HBO or LIPUS treatment significantly increased the gene expressions of aggrecan (Figure 4) and type-II collagen (Figure 5) in OA chondrocytes as compared with the control cells.

\section{Discussion}

The secretion of proteolytic enzymes by the cartilage has been confirmed to contribute to the loss of extracellular matrix in OA. MMPs are capable of degrading the macromolecules of connective tissue matrices and have been considered the major proteases responsible for the pathologic destruction of tissue [21]. Moreover, an imbalance

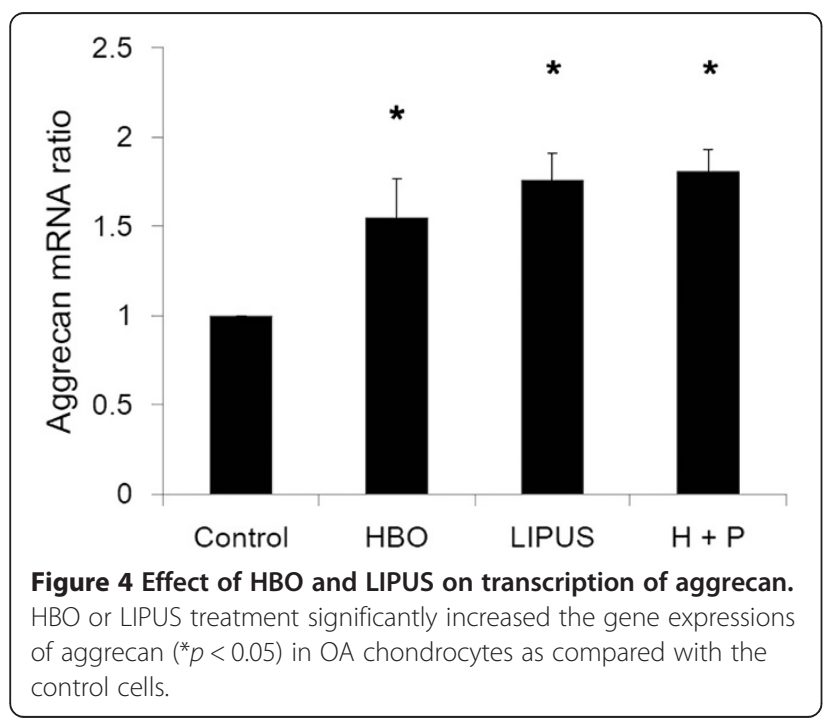

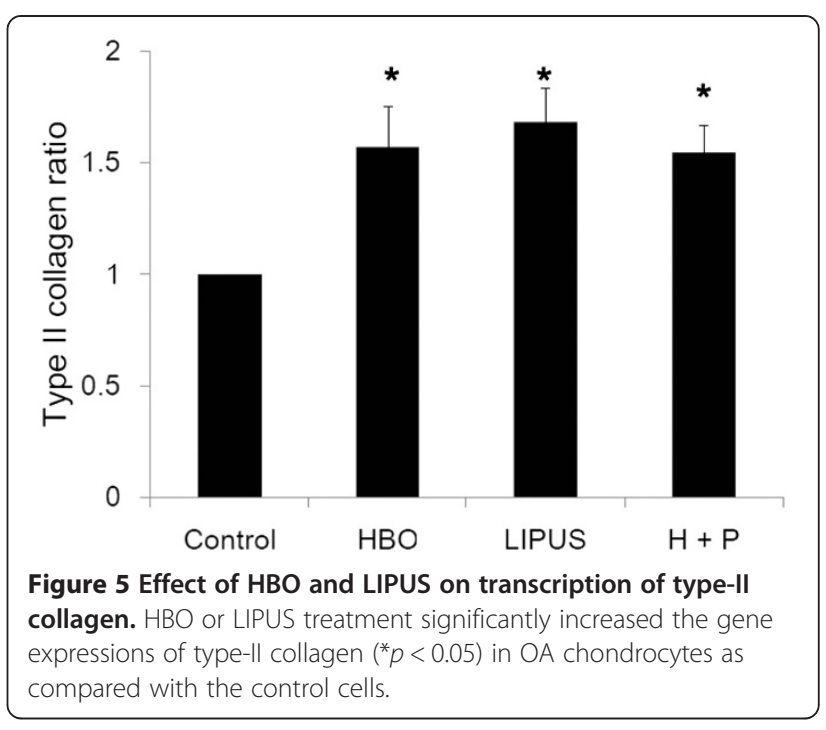

between MMPs and their inhibitors, tissue inhibitors of metalloproteinases (TIMPs), is responsible for the pathogenic sequence of cartilage degradation [22].

To elucidate whether mechanical stimulation by LIPUS combined with $\mathrm{HBO}$ treatment is chondrocyte-protective, we studied the effect of LIPUS combined with HBO treatment at several intensities on the protein expression of MMPs and TIMPs. LIPUS may potentially protect articular cartilage by inhibiting MMP-13 and MMP-1 mRNA expression in an intensity-dependent manner [23]. TIMP-1 mRNA expression was inhibited significantly by LIPUS stimulation of the articular cartilage explants at $67 \mathrm{~mW} / \mathrm{cm}^{2}$ but up-regulated by the stimulation of the cultured chondrocytes at $30 \mathrm{~mW} / \mathrm{cm}^{2}$ [23]. In the present study, the MMP-3 production was significantly downregulated by the $\mathrm{HBO}$ treatment but not by the LIPUS stimulation (Figure 1). The TIMP-1 production in OA chondrocytes was significantly up-regulated by the $\mathrm{HBO}$ or LIPUS treatment (Figure 2). We further showed that $\mathrm{HBO}$ combined with LIPUS treatment resulted in an additive effect in the TIMP-1 production (Figure 2). HBO combined with LIPUS treatment-induced increase of the anabolic factor (TIMP-1)/catabolic factor (MMP-3) ratio may provide a therapeutic approach to slow the course of OA chondrocyte degeneration.

Nitric oxide (NO) is a highly reactive nitrogen radical implicated in multiple biological processes, including regulation of vascular tone, platelet and leukocyte adhesion, neurotransmission, mediation of excessive vasodilatation, and cytotoxic actions of macrophages against microbes and tumor cells [24]. Ultrasound stimulates NF- $\mathrm{kB}$ activation and iNOS expression in cultured preosteoblasts [25]. Exposure to LIPUS increases NO and prostaglandin release, which are required for mechanically induced bone formation [26]. However, apoptosis of chondrocytes can be induced by NO $[10,16,27]$. HBO 
treatment prevents NO-induced apoptosis in articular cartilage injury via enhancement of the expression of heat shock protein 70 [20]. In the present study, HBO suppressed while LIPUS increased the gene expressions of iNOS in OA chondrocytes (Figure 3). HBO combined with LIPUS treatment resulted in compensatory effect in iNOS expression in OA chondrocytes (Figure 3), thus may prevent $\mathrm{NO}$-induced apoptosis.

HBO treatment increased PG synthesis in vivo $[19,20]$. However, the effect of LIPUS to stimulate chondrocyte matrix synthesis is still controversial. Several in vitro studies have been undertaken to characterize the effects of LIPUS on chondrocytes in both monolayer and 3D model systems. These studies report the up-regulation of aggrecan and collagen II genes [28-30] and GAG synthesis [31]. However, conflicting reports suggest that LIPUS induces, at best, a transient effect on chondrocyte culture systems in terms of GAG and collagen II production [32] and aggrecan gene expression [33]. In the present study, similar results suggested that the aggrecan and type-II collagen mRNA expression in the OA chondrocytes were significantly up-regulated by $\mathrm{HBO}$ treatment. However, there was no additive effect in aggrecan and type-II collagen mRNA expression by $\mathrm{HBO}$ combined with LIPUS treatment (Figures 4 and 5).

In this paper, the author combined a chemical factor (hyperbaric oxygen) and a mechanical factor (LIPUS) treatment. The weighting of these two factors are equal in the combined treatment, and the induced increase of the (TIMP-1)/catabolic factor (MMP-3) ratio may provide an additive therapeutic approach to slow the course of OA degeneration. Although the effects of the combined factors are better than those of a single factor, the optimal combination ratio of these two factors needs further investigation.

\section{Conclusion}

HBO combined with LIPUS treatment resulted in an additive effect in the TIMP-1 production and a compensatory effect in iNOS expression. Therefore, we will apply similar techniques of HBO combined with LIPUS therapy in future studies of cartilage injury models. The advantage of HBO combined with LIPUS treatment is that it is a useful tool for clinics and a more applicable clinical therapy.

\section{Competing interests}

The authors declare that they have no competing interests.

\section{Authors' contributions}

LJY, SWNU, and CCN designed the study. SSL and CYY analyzed and interpreted the data. CCN, YSC, and WJC provided the study materials and patients. SSL and SWNU drafted the manuscript. All authors read and approved the final manuscript.

\section{Acknowledgements}

This research was supported in part by grants from the National Science Council and Chang Gung Memorial Hospital (CMRPG381441), Taiwan, Republic of China.

\section{Author details}

${ }^{1}$ Department of Orthopaedic Surgery, Chang Gung Memorial Hospital, 5, Fu-Hsin St. 333, Kweishan, Taoyuan 333, Taiwan. ${ }^{2}$ Graduate Institute of Biomedical Sciences, Chang Gung University, 259 Wen-Hwa 1st Road, Taoyuan 333, Taiwan.

Received: 4 November 2013 Accepted: 17 January 2014

Published: 5 February 2014

\section{References}

1. Sun HB: Mechanical loading, cartilage degradation, and arthritis. Ann N Y Acad Sci 2010, 121:37-50.

2. Fujisawa T, Hattori T, Takahashi K, Kuboki T, Yamashita A, Takigawa M: Cyclic mechanical stress induces extracellular matrix degradation in cultured chondrocytes via gene expression of matrix metalloproteinases and interleukin-1. J Biochem 1999, 125:966-975.

3. Leong DJ, Gu XI, Li YH, Lee JY, Laudier DM, Majeska RJ, Schaffler MB, Cardoso L, Sun HB: Matrix metalloproteinase-3 in articular cartilage is up-regulated by joint immobilization and suppressed by passive joint motion. Matrix Biol 2010, 29:420-426.

4. Smith RL, Lindsey DP, Dhulipala L, Harris AHS, Goodman SB, Maloney WJ: Effects of intermittent hydrostatic pressure and BMP-2 on osteoarthritic human chondrocyte metabolism in vitro. J Orthop Res 2011, 29:361-368.

5. Torzilli PA, Bhargava M, Park S, Chen CTC: Mechanical load inhibits IL-1 induced matrix degradation in articular cartilage. Osteoarthritis Cartilage 2010, 18:97-105.

6. Trindade MCD, Shida J, Ikenoue T, Lee MS, Lin EY, Yaszay B, Yerby S, Goodman SB, Schurman DJ, Smith RL: Intermittent hydrostatic pressure inhibits matrix metalloproteinase and pro-inflammatory mediator release from human osteoarthritic chondrocytes in vitro. Osteoarthritis Cartilage 2004, 12:729-735.

7. Duarte LR: The stimulation of bone growth by ultrasound. Acta Orthop Traumatol Surg 1983, 101:153-159.

8. Ikeda K, Takayama T, Suzuki N, Shimada K, Otsuka K, Ito K: Effects of low-intensity pulsed ultrasound on the differentiation of $\mathrm{C} 2 \mathrm{C} 12$ cells. Life Sci 2006, 79:1936-1943.

9. Wiltink A, Nijweide PJ, Oosterbaan WA, Hekkenberg RT, Helders PJ: Effect of therapeutic ultrasound on endochondral ossification. Ultrasound Med Biol 1995, 21:121-127.

10. Nolte PA, Klein-Nulend J, Albers GH, Marti RK, Semeins CM, Goei SW, Burger EH: Low-intensity ultrasound stimulates endochondral ossification in vitro. J Orthop Res 2001, 19:301-307.

11. Warden SJ, Bennell KL, McMeeken JM, Wark JD: Acceleration of fresh fracture repair using the sonic accelerated fracture healing system (SAFHS): a review. Calcif Tissue Int 2000, 66:157-163.

12. Tien YC, Lin SD, Chen CH, Lu CC, Su SJ, Chih TT: Effects of pulsed low-intensity ultrasound of human child chondrocytes. Ultrasound Med Biol 2008, 34:1174-1181.

13. Hasanova GI, Noriega SE, Mamedov TG, Thakurta SG, Turner JA, Subramanian A: The effect of ultrasound stimulation on the gene and protein expression of chondrocytes seeded in chitosan scaffolds. J Tissue Eng Regen Med 2011, 5:15-822.

14. Cook SD, Salkeld SL, Popich-Patron LS, Ryaby JP, Jones DG, Barrack RL: Improved cartilage repair after treatment with low-intensity pulsed ultrasound. Clin Orthop 2001, 391(Suppl):S231-S243.

15. Huang MH, Yang RC, Ding HJ, Chai CY: Ultrasound effect on level of stress proteins and arthritic histology in experimental arthritis. Arch Phys Med Rehabil 1999, 80:551-556.

16. Samali A, Orrenius S: Heat shock proteins: regulators of stress response and apoptosis. Cell Stress Chaperones 1998, 3:228-236.

17. Niu CC, Yuan LJ, Chen LH, Lin SS, Tsai TT, Liao JC, Lai PL, Chen WJ: Beneficial effects of hyperbaric oxygen on human degenerated intervertebral disk cells via suppression of IL-1 $\beta$ and p38 MAPK signal. J Orthop Res 2011, 29:14-19.

18. Medzhitov R: Toll-like receptors and innate immunity. Nat Rev Immunol 2001, 1:135-145. 
19. Yuan $L$, Ueng SWN, Lin SS, Yeh WL, Yang CY, Lin PY: Attenuation of apoptosis and enhancement of proteoglycan synthesis in rabbit cartilage defects by hyperbaric oxygen treatment are related to the suppression of nitric oxide production. J Orthop Res 2004, 22:1126-1134.

20. Ueng SWN, Yuan LJ, Lin SS, Niu CC, Chan YS, Wang IC, Yang CY, Chen WJ: Hyperbaric oxygen treatment prevents nitric oxide-induced apoptosis in articular cartilage injury via enhancement of the expression of heat shock protein 70. J Orthop Res 2013, 31:376-384.

21. Blain EJ: Mechanical regulation of matrix metalloproteinases. Front Biosci 2007, 12:507-527.

22. Kafienah W, Al-Fayez F, Hollander AP, Barker MD: Inhibition of cartilage degradation: a combined tissue engineering and gene therapy approach. Arthritis Rheum 2003, 48:709-718.

23. Ito A, Aoyama T, Yamaguchi S, Zhang X, Akiyama H, Kuroki H: Low-intensity pulsed ultrasound inhibits messenger RNA expression of matrix metalloproteinase-13 induced by interleukin- $1 \beta$ in chondrocytes in an intensity-dependent manner. Ultrasound Med Biol 2012, 38:1726-1733.

24. Nathan C, Xie QW: Nitric oxide synthases roles, tolls, and controls. Cell 1994, 78:915-918.

25. Hou CH, Lin J, Huang SC, Hou SM, Tang CH: Ultrasound stimulates NF-kb activation and iNOS expression via the Ras/Raf/MEK/ERK signaling pathway in cultured preosteoblasts. J Cell Physiol 2009, 220:196-203.

26. Tang CH, Yang RS, Huang TH, Lu DY, Chuang WJ, Huang TF, Fu WM: Ultrasound stimulates cyclooxygenase-2 expression and increases bone formation through integrin, focal adhesion kinase, phosphatidylinositol 3-kinase, and Akt pathway in osteoblasts. Mol Pharmacol 2006, 69:2047-2057.

27. Yuan $\amalg$, Niu CC, Lin SS, Chan YS, Yang CY, Chen WJ, Ueng SWN: Additive effects of hyperbaric oxygen and platelet-derived growth factor-BB in chondrocytes transplantation via up-regulation expression of plateletderived growth factor- $\beta$ receptor. J Orthop Res 2009, 27:1439-1446.

28. Zhang ZJ, Huckle J, Francomano CA, Spencer RGS: The effects of pulsed low-intensity ultrasound (PLIUS) on chondrocyte viability, proliferation, gene expression and matrix production. Ultrasound Med Biol 2003, 29:1645-1651

29. Mukai S, Ito H, Nakagawa Y, Akiyama H, Miyamoto M, Nakamura T: Transforming growth factor-beta(1) mediates the effects of lowintensity pulsed ultrasound in chondrocytes. Ultrasound Med Biol 2005, 31:1713-1721

30. Zhang ZJ, Huckle J, Francomano CA, Spencer RGS: The influence of pulsed low-intensity ultrasound on matrix production of chondrocytes at different stages of differentiation: an explant study. Ultrasound Med Biol 2002, 28:1547-1553

31. Kopakkala-Tani M, Leskinen JJ, Karjalainen HM, Karjalainen T, Hynynen K, Toyras J, Jurvelin JS, Lammi MJ: Ultrasound stimulates proteoglycan synthesis in bovine primary chondrocytes. Biorheology 2006, 43:271-282.

32. Korstjens $C M$, van der Rijt RHH, Albers GHR, Semeins CM, Klein-Nulend J: Low-intensity pulsed ultrasound affects human articular chondrocytes in vitro. Med Biol Eng Comput 2008, 46:1263-1270.

33. Zhang ZJ, Huckle J, Francomano CA, Spencer RGS: The effects of pulsed low-intensity ultrasound on chondrocyte viability, proliferation, gene expression and matrix production. Ultrasound Med Biol 2003, 29:1645-1651. 1222.

doi:10.1186/1749-799X-9-5

Cite this article as: Yuan et al:: Effects of low-intensity pulsed ultrasound and hyperbaric oxygen on human osteoarthritic chondrocytes. Journal of Orthopaedic Surgery and Research 2014 9:5.

\section{Submit your next manuscript to BioMed Central and take full advantage of:}

- Convenient online submission

- Thorough peer review

- No space constraints or color figure charges

- Immediate publication on acceptance

- Inclusion in PubMed, CAS, Scopus and Google Scholar

- Research which is freely available for redistribution

Submit your manuscript at www.biomedcentral.com/submit
C Biomed Central 